\title{
Economic viability of implementing an infrastructure for recycling bedding sand from a free-stall facility for dairy cows
}

\section{Viabilidade econômica da implantação da infraestrutura para recuperação da areia da cama de uma instalação free stall para vacas leiteiras}

\begin{abstract}
Marcos Aurélio Lopes ${ }^{1 *} ;$ Fabiana Alves Demeu ${ }^{2}$; Eduardo Mitke Brandão Reis ${ }^{3}$; André Luis Ribeiro Lima4; Francisval de Melo Carvalho4; Julio Cesar Pascale Palhares5; Geraldo Márcio da Costa6; Marcelo Vinícius Gontijo Pinheiro7; Andréia Alves Demeu ${ }^{8}$
\end{abstract}

\section{Highlights}

The economic viability of recycling bedding sand from a free-stall was analyzed.

The MOP scenario analysis (optimistic, most likely and pessimistic scenarios) was carried out.

Sand recycling was economically viable in all scenarios.

Net present value was positive and internal rate of return was above the hurdle rate.

Simple and discounted payback and cost-benefit ratio were satisfactory.

\begin{abstract}
This study proposes to examine the economic viability of implementing the necessary infrastructure for the recycling of bedding sand from a free-stall facility in a milk production system in southern Minas Gerais, Brazil. In specific terms, the total production cost (TC), total operating cost (TOC) and effective operating cost (EOC) of a cubic meter of recycled sand were estimated in order to estimate the total sand consumption for the free-stall system and per bed year ${ }^{-1}$ as well as the equilibrium point of the amount of recycled sand, in

1 Prof. Titular, Departamento de Medicina Veterinária, Universidade Federal de Lavras, UFLA, Lavras, MG, Brasil. E-mail: malopes@ufla.br

2 Discente de Doutorado, Instituto Federal de Rondônia, IFRO, RO, Brasil. E-mail: fabiana.alves@ifro.edu.br

3 Prof., Universidade Federal do Acre, UFAC, Rio Branco, AC, Brasil. E-mail: edumitke@gmail.com

4 Profs., Departamento de Administração e Economia, UFLA, Lavras, MG, Brasil. E-mail: andre.lima@ufla.br; francarv@ ufla.br

5 Pesquisador, Empresa Brasileira de Pesquisa Agropecuária, EMBRAPA Pecuária Sudeste, São Carlos SP, Brasil. E-mail: julio.palhares@embrapa.br

${ }_{6}$ Prof., Departamento de Medicina Veterinária, UFLA, Lavras, MG, Brasil. E-mail: marciocostavet@gmail.com

7 Médico Veterinário, Autônomo, llícinea, MG, Brasil. E-mail: marcelovgpveterinario@gmail.com

8 Zootecnista, Autônoma, Porto Velho, RO, Brasil. E-mail: demeuaa@gmail.com

* Author for correspondence
\end{abstract}

Received: June 05, 2020 - Approved: Sept. 24, 2020 
cubic meters. The experiment was carried out on a farm located in the south of Minas Gerais from January 2016 to December 2017. Three scenarios were analyzed by the tree-point estimation method (MOP - most likely, optimistic, and pessimistic). Utilization of $85 \%, 95 \%$ and $75 \%$ of the recycled sand was considered for scenarios 1, 2 and 3, respectively. In all of them, the value charged per cubic meter of sand by a supplier close to the farm was considered. Monte Carlo simulation was also carried out with hurdle rates (HR) of up to $90 \%$. Under the studied conditions, sand recycling showed to be economically viable in all scenarios, with positive net present values (NPV), internal rates of return above the HR, simple and discounted payback below the 10-year horizon, and satisfactory cost benefit ${ }^{-1}$ ratios (greater than 1). The EOC of one cubic meter of recycled sand was estimated at $\mathrm{R} \$ 5.04, \mathrm{R} \$ 4.51$ and $\mathrm{R} \$ 5.72$ for scenarios 1,2 and 3 , respectively, whereas the average $\mathrm{TC}$, considering all scenarios, was $\mathrm{R} \$ 6.84(+0.81)$, which is less than the acquisition price of $R \$ 28.57$ at the sand extraction site. The TC was $R \$ 37,219.51$ and $R \$ 34,637.74$ for the scenarios with $H R$ of 8.50 and $6.99 \%$, respectively, whereas TOC was $R \$ 22,572.08$ in all analyzed scenarios. The estimated total annual sand consumption by the free-stall system was $526.44 \mathrm{~m}^{3}$, with an estimated average of 1.23 $\mathrm{m}^{3}(+0.28)$ bed $^{-1}$ year $^{-1}$. All Monte Carlo simulation models showed positive NPV as well as HR of up to $90 \%$, which reflect a high probability of positive NPV.

Key words: Scenario analysis. Dairy cattle farming. Profitability indicators. Reuse. Sustainability.

\section{Resumo}

Objetivou-se analisar a viabilidade econômica da implantação da infraestrutura necessária para a recuperação da areia da cama de uma instalação free stall, em um sistema de produção de leite no Sul de Minas Gerais. Especificamente, pretendeu-se estimar o custo total de produção (CT), custo operacional total (COT) e custo operacional efetivo (COE) de um metro cúbico de areia recuperada, estimar o consumo total de areia para o sistema free stall, e por cama $a n o^{-1}$ e estimar o ponto de equilíbrio da quantidade de areia recuperada, em metros cúbicos. A pesquisa foi realizada em uma propriedade localizada no Sul de Minas Gerais; no período de janeiro de 2016 a dezembro de 2017. Realizou-se a análise de cenários MOP: mais provável (cenário 1); otimista (cenário 2); e pessimista (cenário 3). Considerou-se o aproveitamento de 85\%, $95 \%$ e $75 \%$ da areia recuperada para os cenários 1, 2 e 3, respectivamente. Em todos eles, foi considerado o valor praticado por metro cúbico da areia em um fornecedor próximo à propriedade. Realizou-se, ainda, simulação de Monte Carlo com taxas mínimas de atratividade de até 90\%. A recuperação de areia, nas condições estudadas, apresentou viabilidade econômica em todos os cenários, apresentando valor presente líquido (VLP) positivos, taxas internas de retorno (TIR) acima da taxa mínima de atratividade, payback simples e descontados abaixo do horizonte de 10 anos e relações benefício custo-1 (RBC) satisfatórias (maior que 1). O COE de um metro cúbico de areia recuperada foi estimado em $R \$ 5,04 ; R \$ 4,51$ e $R \$ 5,72$ para os cenários 1; 2 e 3, respectivamente, enquanto que o CT médio, considerando todos os cenários, foi de $R \$ 6,84(+0,81)$, abaixo dos valores de aquisição no areal, que seria de $R \$ 28,57$. Os CT foram de $R \$ 37.219,51$ e $R \$ 34.637,74$ para os cenários com taxa mínima de atratividade de 8,50 e 6,99\%, respectivamente, enquanto que COT foi de $\mathrm{R} \$ 22.572,08$ em todos os cenários analisados. O consumo total de areia anual estimado foi de $526,44 \mathrm{~m}^{3}$ e um consumo médio estimado de $1,23 \mathrm{~m}^{3}(+0,28)$ cama $^{-1}$ ano $^{-1}$. Todos os modelos de simulação de Monte Carlo apresentaram VPL positivos, assim como taxas mínimas de atratividade de até $90 \%$, que refletem alta probabilidade de VPL positivo.

Palavras-chave: Análise de cenários. Bovinocultura leiteira. Indicadores de rentabilidade. Reuso. Sustentabilidade. 


\section{Introduction}

Sustainability in livestock farming has been the concern of several researchers and the object of research in many studies, e.g. a) the use of the DfD (Design for Deconstruction) concept, which has the potential to limit the environmental impact of construction by supporting disassembly and reuse of building materials at the end of life, thus reducing the use of concrete (Leso, Conti, Rossi, \& Barbari, 2018); b) the use of raw earth (unfired clay bricks) as material for building facilities to replace more expensive materials which have inferior thermal characteristics and cause greater environmental impact (Barbari, Monti, Rossi, Simonini, \& Guerri, 2014a,b); c) cereal straw packed in rectangular bales as done directly after harvesting in the field, which is increasingly used in buildings as an element for filling walls due to its high sustainability (Conti et al., 2017); and d) facilities designed considering the needs of outdoor animals and the choice of suitable construction materials available in the region (Rossi, Conti, Bambi, Monti, \& Barbari, 2018).

Sand is one of the most widely used bedding materials in free-stall systems, but is also among the inputs employed in cattle farming with the potential to cause environmental impact. According to several authors, its use is underpinned on it being an inorganic material that provides reasonable hygiene and health conditions to animals (Cook, Weitzman, Auinger, Nguyen, \& Dietz, 2003; Espejo, Endres, \& Salfer, 2006; Norring et al., 2008). Once used, not many proposals exist for its destination, which results in disposal without environmental management. One of the alternatives for the rational use of this material is recycling. In the adoption of this technique, sand can be recycled at the very farm, allowing a reduction in its purchase and, consequently, disbursements on this input. Additionally, the technique represents an environmental benefit, as both the removal of sand from rivers and its transportation will be minimized. In this way, it can contribute to the economic and environmental sustainability of dairy cattle farming.

Lelles, Silva, Griffith and Martins (2005) identified 35 negative environmental impacts related to the so-called sand extraction activity in water courses, while Tobias, Rocha, Ferreira and Sousa (2010) found 10 negative environmental impacts. Ako et al. (2014) also mentioned destruction of landscape, riverbank collapse, deforestation and water pollution as environmental effects that stem from the extraction of sand. In addition to extraction, it is important to consider the environmental impacts generated by the transport, storage and even disposal of this material. As stated by Brondino, Silva and Brondino (2014), large sand discharges contribute to the desertification process, which directly affects populations that depend on planting and conservation areas. These studies show that the activity has a high potential for impact.

Few articles have been found on sand recycling, in the scientific literature (Bradley et al., 2018; Kristula, Rogers, Hogan, \& Sabo, 2005; Kumar et al., 2016; Zdanowicz, Shelford, Tucker, Weary, \& Keyserlingk, 2004), and none of them evaluate its economic viability. Thus, the present study proposes to examine the economic viability of implementing the necessary infrastructure for the recycling of bedding sand from a free-stall facility in a milk production system in southern Minas Gerais, Brazil. In specific terms, the total cost (TC), total operating cost (TOC) and effective operating 
cost (EOC) of a cubic meter of recycled sand were estimated in order to estimate the total sand consumption for the free-stall system and per bed year-1 as well as the equilibrium point in cubic meters of recycled sand.

\section{Material and Methods}

The research was carried out on a farm located in the south of the state of Minas Gerais, Brazil, from January 2016 to December 2017. The farm holds an intensive dairy farming activity with housing for all lactating and pre-calving cows, in two free-stall sheds with dimensions of $90 \times 30 \mathrm{~m}$ (shed 1) and 60 $\mathrm{m} \times 30 \mathrm{~m}$ (shed 2). These stalls have 230 and 198 single beds, respectively, and capacity to house approximately 428 Holstein cows. Average daily yield was 11,864.95 ( $\pm 1,388.79)$ $\mathrm{L}$ and, approximately, 32.28 ( \pm 2.68 ) $\mathrm{L}$ of milk per lactating cow, from three milking sessions. The complete diet, with maize silage (Zea mays) and concentrate, was provided on a feeding lane three times daily.

Two different stages were considered in the survey of information, following the methodology used by Lopes et al. (2019) and Pelegrini et al. (2019). In the first, using a form and a field booklet, a complete inventory of the infrastructure and assets used was carried out aiming to estimate depreciation and the invested capital. Subsequently, the items were allocated to one of the following groups: improvements, machinery and implements.

Each of the improvements (chutes, manholes, tanks and sand separation lanes) was measured and a summary of the complete specifications and drawings was recorded. A value per square meter of construction was estimated depending on the area, preservation state and finishing standard. The current value used was the product of the square meter value by the improvement area (Lopes et al., 2019). The group of machinery and implements included a Valtra A850 tractor (year 2015) with front blade, a Valtra 685 tractor with ladle and an Agromix tractor trailer with capacity for one ton (year 2014).

In the second stage, the production system was visited and the files were consulted for data collection regarding actual operating expenses, using field handbooks prepared for this purpose. The items that make up the effective operating cost (EOC) of sand recycling were divided into the following groups: labor, taxes considered fixed, maintenance and miscellaneous expenses. For the item of infrastructure maintenance, the percentage of $4 \%$ of assets value was adopted (Haack \& Oliveira, 2013). For the return on working capital, the rates of 8.50 and $6.99 \%$ were adopted, considering $20 \%$ of the EOC, as recommended by Lopes et al. (2016). The data were recorded in a spreadsheet with two production cost structures, namely, Total Production Cost, which involves fixed and variable costs, and Operating Costs, both used by Lopes et al. (2019) and Pelegrini et al. (2019). In this study, the straight-line depreciation method used by Moraes et al. (2018) was adopted. For the depreciation of machinery and implements used to stir the sand, an apportionment criterion was employed, considering only $12 \%$ of the value; the remainder (88\%) was computed for the milk production cost center. These values were estimated based on the number of hours worked.

The sand recycling system consisted of recycling the sand removed from the freestall beds and sand from the handling of the 
animals (displacement throughout the facility and milking). The sand was transported by flushing and deposited in a decantation pit. After the effluent was drained, the sand was removed with a loader and taken to dry in the sun, where it remained for a minimum of 20 days and was stirred two to three times weekly. The moment of return to the free-stall beds was determined based on visual (color) and tactile (moisture) assessment. To prevent mastitis, lime was applied on the beds every day. To estimate the amount of sand recycled, the difference between the purchased amount, as stated in the invoices, before and after the implementation of the sand recycling system was considered. The average price of one cubic meter of sand was estimated considering the invoices, referring to the months of data analysis.

In cash flow, revenue was considered as the volume of recycled sand, in cubic meters, multiplied by the value charged by the sand supplier, plus the shipping cost saved with the reuse of sand. The following indicators were estimated: Net Present Value (NPV), Internal Rate of Return (IRR); simple and discounted payback, according to the methodology used by Lopes, Junqueira, Brunh, Demeu and Silva (2017) and Lopes et al. (2018), and the cost benefit ${ }^{-1}$ ratio used by Haraguchi, Siddiqi and Narayanamurti (2019). A 10-year horizon was adopted in the estimation of these indicators. For the discount rate, two scenarios were simulated: $8.50 \%$ per year, which is the financing rate available to rural producers willing to implement activities of this magnitude; and $6.99 \%$, which was the cumulative savings interest rate in the year 2017 (Portal Brasil, 2017).

Three scenarios were analyzed by the tree-point estimation method (most likely [1], optimistic [2], and pessimistic [3]), as adopted by Lage et al. (2016). Scenario 1 considered $85 \%$ reuse of the sand. In the optimistic scenario (2), this value was $95 \%$. Finally, for the pessimistic scenario (3), a recovered percentage of $75 \%$ was considered. In all three scenarios, the adopted value of one cubic meter of sand was that charged by a supplier close to the farm.

Additionally, two models were developed for Monte Carlo Simulation (MCS) (Laponni, 2007), using Microsoft Office Excel'. For the construction of the models, the following variables were applied: unit value paid per cubic meter of sand of $\mathrm{R} \$ 50.00$ and $\mathrm{R} \$ 54.00 ; 10 \%$ discount rate; 10 -year project horizon; and hurdle rates (HR) of 10 to $90 \%$. Each variable used was determined from the collected data considering the structure of the very analyzed farm.

Monte Carlo simulation is a tool used in investment projects, whose premise is the generation of random numbers correlated with cash inflows and outflows, the basis for calculating NPV and IRR. The random changes in cash flow function work as random scenarios, allowing numerous possibilities of future outcomes (Torres, 2006). Random numbers are generated from a predefined distribution based on historical data and experiences of the analyst (M. H. F. Oliveira, Almeida, \& Rebelatto, 2009). The input data are random data related to the sand recycling process. Thus, it was necessary to know the amount of sand recycled, as it was what defined the calculation of the estimated amount of sand that would be recycled. In view of the minimum and maximum values, the spreadsheet and the triangular function proposed by Laponni (2007) were used, in which 1,000 possible values were generated for each variable, 
allowing the descriptive statistical analysis of the data. Net present value means the value of future payments discounted at an appropriate interest rate minus the cost of the initial investment (A. D. Oliveira \& Macedo, 1996).

The economic indices were compared, through descriptive analyses, using MS Excel ${ }^{\circledR}$ software and grouped in tables for a better comparison, discussion and presentation of the results (Lopes et al., 2019).

\section{Results and Discussion}

A summary of the resources required for the recycling of sand is given in Table 1. The highest value corresponded to improvements, which accounted for $53.56 \%$ of investments. Despite its lower percentage (5.94\%) when compared with the other groups, the area for the sand to be stirred should be taken into account, because if not for this purpose it could be used for another production activity. Comparisons of values and percentages for sand recycling were not possible, as no studies on the topic were found in the scientific literature.

\section{Table 1}

Resources used to implement the infrastructure for the recycling of bedding sand from a free stall facility for dairy cows in southern Minas Gerais, in the period from 2016 to 2017, in R\$ and US\$

\begin{tabular}{lccc|}
\hline Specification & Value (R\$) & Value (US\$) & (\%) \\
\hline Land equity value & $\mathbf{1 0 , 5 8 3 . 1 6}$ & $\mathbf{3 , 2 4 6 . 3 7}$ & $\mathbf{5 . 9 4}$ \\
\hline Equity value without land & $\mathbf{1 6 7 , 5 7 5 . 3 6}$ & $\mathbf{5 3 , 4 0 3 . 4 9}$ & $\mathbf{9 4 . 0 6}$ \\
\hline Improvements value & $95,415.36$ & $29,268.51$ & 53.56 \\
\hline Equipment and implements & $54,400.00$ & $16,687.12$ & 30.53 \\
\hline Machinery value & $17,760.00$ & $5,447.85$ & 9.97 \\
\hline Total fixed assets & $\mathbf{1 7 8 , 1 5 8 . 5 2}$ & $\mathbf{5 4 , 6 4 9 . 8 5}$ & $\mathbf{1 0 0 . 0 0}$ \\
\hline Fixed assets per housed cow & 416.26 & 127.69 & 0.23
\end{tabular}

US\$1.00 = R\$3.26, average quote from 01/01/2017 to 12/31/2017 (Banco Central do Brasil [BCB], 2018).

The fixed asset per housed cow, of $\mathrm{R} \$ 416.26 \quad(0.23 \%$ of the sand recycling infrastructure), represented only $2.03 \%$ of the fixed $\mathrm{R} \$ 20,466.11$ (US\$6,277.95) housed cow ${ }^{-1}$ of the production system, disregarding the land.

The most likely scenario (1), practiced on the farm during the data collection period, proved to be promising, since, in addition to helping preserve the environment, it also provided a positive NPV; IRR above the HR and simple and discounted payback below the proposed horizon (Table 2). Scenario 2 (optimistic) provides the best use of available resources and provided higher net cash flows, due to the efficiency in the use of sand (95\%). The greatest efficiency of utilization can be achieved by covering the sand with tarps during rainfall events, which will prevent it from drenching, allowing a faster drying as well as reducing losses due to surface runoff. It is worth mentioning that this practice will incur additional costs with tarps and labor. Scenario 3 (pessimistic) would provide the lowest recovery of sand (75\%), but, even so, it showed promising indicators of economic viability. 


\section{Table 2}

Economic indicators for the implementation of infrastructure for the recycling of bedding sand from a free-stall facility for dairy cows in the south of Minas Gerais, from January 2016 to December 2017, considering different discount rates (DR)

\begin{tabular}{|c|c|c|c|c|c|c|c|c|c|c|c|c|}
\hline \multirow{2}{*}{ Specification } & \multicolumn{4}{|c|}{ Scenario 1: most likely } & \multicolumn{4}{|c|}{ Scenario 2: optimistic } & \multicolumn{4}{|c|}{ Scenario 3: pessimistic } \\
\hline & \multicolumn{2}{|c|}{$8.50 \%$ DR } & \multicolumn{2}{|c|}{$6.99 \%$ DR } & \multicolumn{2}{|c|}{$8.50 \% \mathrm{DR}$} & \multicolumn{2}{|c|}{$6.99 \% \mathrm{DR}$} & \multicolumn{2}{|c|}{$8.50 \% \mathrm{DR}$} & \multicolumn{2}{|c|}{$6.99 \% \mathrm{DR}$} \\
\hline NPV $(R \$)$ & \multicolumn{2}{|c|}{$900,328.50$} & \multicolumn{2}{|c|}{$998,926.41$} & \multicolumn{2}{|c|}{$1,030.541 .76$} & \multicolumn{2}{|c|}{$1,138.377 .38$} & \multicolumn{2}{|c|}{$770,115.25$} & \multicolumn{2}{|c|}{$850,592.05$} \\
\hline IRR (\%) & \multicolumn{2}{|c|}{119.47} & \multicolumn{2}{|c|}{124.89} & \multicolumn{2}{|c|}{134.57} & \multicolumn{2}{|c|}{140.36} & \multicolumn{2}{|c|}{104.36} & \multicolumn{2}{|c|}{107.61} \\
\hline Benefit cost ${ }^{-1}$ & \multicolumn{2}{|c|}{7.84} & \multicolumn{2}{|c|}{8.78} & \multicolumn{2}{|c|}{8.83} & \multicolumn{2}{|c|}{9.86} & \multicolumn{2}{|c|}{6.85} & \multicolumn{2}{|c|}{4.30} \\
\hline Payback & 1S & ${ }^{2} \mathrm{D}$ & ${ }^{1 S}$ & ${ }^{2} \mathrm{D}$ & 1S & ${ }^{2} \mathrm{D}$ & ${ }^{1 S}$ & ${ }^{2} \mathrm{D}$ & ${ }^{1 S}$ & ${ }^{2} \mathrm{D}$ & ${ }^{1 S}$ & ${ }^{2} \mathrm{D}$ \\
\hline Years & 1 & 1 & 1 & 1 & 1 & 1 & 1 & 1 & 1 & 1 & 1 & 1 \\
\hline Months & 2 & 1 & 3 & 1 & 4 & 2 & 4 & 6 & 0 & 1 & 2 & 8 \\
\hline Days & 9 & 6 & 0 & 26 & 24 & 27 & 24 & 11 & 15 & 29 & 12 & 8 \\
\hline
\end{tabular}

1S: Simple payback; D²: Discounted payback.

The implementation of infrastructure for the recycling of sand, under the studied conditions, showed economic viability in all scenarios (Table 2), with positive NPV, which indicates that the investor will have financial gain (Chenço, 2016); IRR above the HR, which means the investment will have financial return; and simple and discounted payback below the proposed horizon (Table 3), meaning it will be possible to recover all the invested capital before the 10-year horizon. The cost benefit ${ }^{-1}$ ratios were satisfactory, indicating that the project costs are lower than the obtained benefits. These results show that, in practical terms, there will be an equity evolution and that this activity constitutes a good investment option for the investor. It should be noted that agricultural production systems need investments to mitigate environmental impacts; however, if not associated with a reduction of costs, it may render the production activity inviable. Therefore, knowing the production system and its costs is necessary, as this will allow maximum use of the productive potential; maximization of profits; and the identification and correction of bottlenecks. In this way, economic and environmental sustainability can be ensured once the environmental impacts caused by the developed activities are reduced.

Table 3 shows a summary of the profitabilityanalysis of the sand recycling activity in all the proposed scenarios. The expected total annual revenue was $\mathrm{R} \$ 168,686.78$, $\mathrm{R} \$ 188,532.29$ and $\mathrm{R} \$ 148,841.28$ for scenarios 1, 2 and 3, respectively. These values correspond to the sum of the values calculated with the recycled sand, which would no longer be purchased, of $\mathrm{R} \$ 96,387.63$ (57.14\%), $\mathrm{R} \$ 107,727.35 \quad(57.14 \%)$ and $\mathrm{R} \$ 85,047.91$ (57.14\%) for scenarios 1, 2 and 3, respectively. Expected savings on shipping expenses would be $\mathrm{R} \$ 72,299.16$ (42.86\%), $\mathrm{R} \$ 80,804.94$ and $\mathrm{R} \$ 63,793.37$ (42.86\%), respectively. The percentages corresponding to the sand purchase values and expected savings on shipping are the same in all scenarios, as the sand purchase and shipping values per cubic meter remain the same. When we compare the scenarios, a difference is only present for the amount of sand that is no longer purchased, which represents savings for the production system because the recycled sand is cheaper than the purchased sand. This results in a higher expected revenue for scenario 2 (optimistic), which has the highest recycled percentage. 


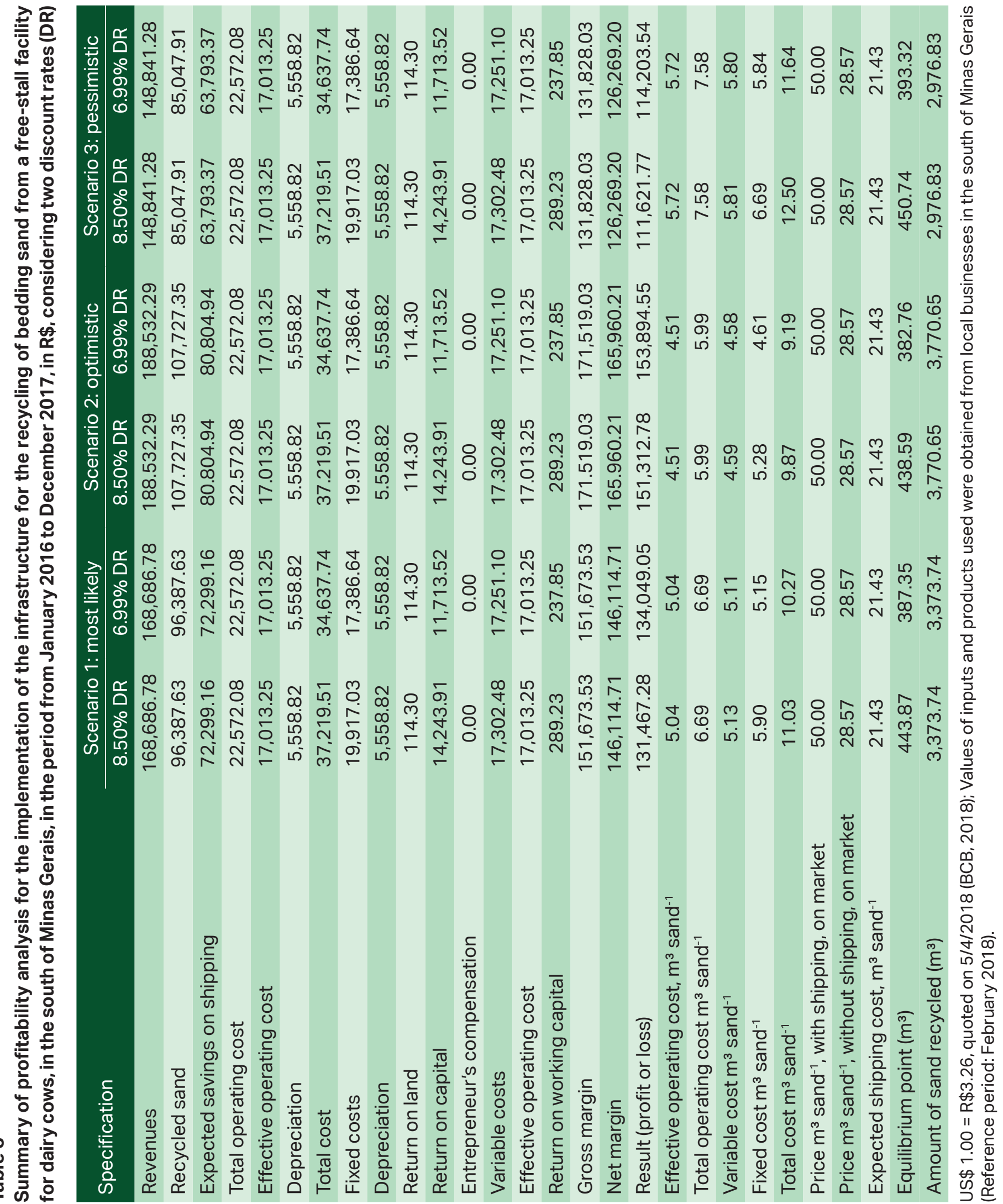


The average TC of one cubic meter of recycled sand, considering all scenarios, was $R \$ 11.24(+13.7)$, which is well below the purchase value at the sand extraction site, which would be $\mathrm{R} \$ 28.57$ for all scenarios. The lowest cost is found in the optimistic scenario, due to better recycling of sand, an estimated $95 \%$. This fact must be taken into account when designing and executing the project, so an infrastructure is constructed that allows maximum recycling of the sand from the freestall beds.

In scenario 2, the TC of one cubic meter of recycled sand was $44.83 \%$ and $32.16 \%$ less than the sand purchase value, respectively, considering interestrates of 6.99 and $8.50 \%$ per year. This is without considering the expected savings on shipping, which represented $37.41 \%$ and $30.01 \%$ of the purchase value of one cubic meter of sand for scenarios 1 and 2 , respectively. The sand purchase and shipping costs and the distance from the farm to the sand supplier can interfere with the economic viability of the sand recycling activity.

The result (profit or loss) was positive in all analyzed scenarios, demonstrating that the activity is able to persist in the long term. In all scenarios, the amount of sand recycled was approximately nine times higher than the equilibrium point, which was 443.87, 438.59 and $450.74 \mathrm{~m}^{3}$ year $^{-1}$ for the HR of $8.50 \%$ in scenarios 1, 2 and 3, respectively.

Rocha and Gaworski (2017) estimated an average loss of $3.53 \mathrm{~m}^{3}$ of sand bed ${ }^{-1}$ year 1 in free-stall systems that do not recycle it. In the evaluated data, the average for the period from January 2016 to December 2017 indicated a loss of $1.23 \mathrm{~m}^{3} \mathrm{bed}^{-1}$ year $^{-1}(+0.28)$. This represents a savings of $2.30 \mathrm{~m}^{3}$ bed $^{-1}$ year ${ }^{1}$ when compared with the results described by
Rocha and Gaworski (2017) and a savings of $\mathrm{R} \$ 65.71$ bed $^{-1}$ year-1, without considering the expected savings on shipping, which would represent an additional $\mathrm{R} \$ 49.29$ bed $^{-1}$ year 1. Thus, in the milk production system of the present study, a savings of $\mathrm{R} \$ 28,123.88$ year $^{-1}$ can be obtained only with the sand that is not lost, which reduced the purchase value of new sand to $1.39 \mathrm{~m}^{3}$ bed $^{-1}$ year $^{-1}$. Additionally, it would represent $0.43 \%$ of the total estimated revenue and $0.94 \%$ of the $\mathrm{EOC}$.

Table 4 shows the descriptive statistics of NPV for MCS1 and MCS2. This analysis contains important information about the results of the events that the manager may encounter during the operational cycle. The minimum NPV of R $\$ 621,698.00$ was observed in MCS2, whereas the maximum value in this simulation was $\mathrm{R} \$ 939,839.00$, which explained the higher coefficient of variation when compared with MCS1. In MCS1 and MCS2, the risks involving the amount of recycled sand were considered, with respective minimum, average and maximum values of $3,773.74$, $3,770.65$ and $2,976.83 \mathrm{~m}^{3}$ year ${ }^{-1}$. These values were adopted because it is estimated on the farm that the highest probability (average) is what has been used at the time of the study. The maximum would be the value estimated with the possibility of covering the sand in periods of rain, and the minimum would be the lowest value considering the possible situations within the production techniques of the farm. In MCS1, the unit and maximum costs per cubic meter of sand were considered $\mathrm{R} \$ 5.10$ of $\mathrm{R} \$ 5.70$, respectively; and in model 2, a minimum unit cost of $\mathrm{R} \$ 5.10$ and a maximum cost of $R \$ 8.00 \mathrm{~m}^{3}$ of sand was adopted, considering a $63.75 \%$ increase in the fuel value. The amount of recycled sand $(2,976.00$, $3,373.00$ and $\left.3,770.00 \mathrm{~m}^{3}\right)$; the fixed cost of 
the sand recycling system $(R \$ 1,357.00)$; the investment in the necessary infrastructure ( $R \$ 77,583.6) ;$ and the variable costs of $R \$ 5.06$ and $\mathrm{R} \$ 5.67$ per cubic meter of recycled sand were also considered. All analyzed scenarios showed positive NPV, indicating a high probability of this economic indicator being above expectations. Therefore, although the investment is advisable, the manager must be aware of the market and of consumption at the farm, especially with respect to shipping.

\section{Table 4}

Statistical summary of the net present value (NPV) for the implementation and use of a bedding sand recycling system for a free-stall facility in the south of Minas Gerais in the years 2016 to 2017, for Monte Carlo simulations 1 (MCS1) and 2 (MCS2)

\begin{tabular}{lcc}
\hline Statistical data & NPV MCS1 & NPV MCS2 \\
\hline Minimum (R\$) & $650,717.00$ & $621,698.00$ \\
\hline Maximum (R\$) & $939,839.00$ & $926,516.00$ \\
\hline Most likely (R\$) & $788,111.00$ & $765,079.00$ \\
\hline Median (R\$) & $786,078.00$ & $765,231.00$ \\
\hline Standard deviation (R\$) & $52,520.00$ & $53,599.00$ \\
CV (\%) & 0.07 & 0.07 \\
\hline Probability of NPV>0 (\%) & 100.00 & 100.00 \\
\hline
\end{tabular}

Table 5 shows the probability of NPV>0 in MCS1 and MCS2, for HR of 10 to $90 \%$. The HR indicated a probability of $100 \%$ success for the business in eight of the nine simulations in MCS1, and in seven of out of nine simulations in MCS2. The HR of 80 and $90 \%$ for MCS2 were 97 and 49\%, respectively. In cases where bank loans are possible, for the studied situations, the results of the simulations (Table 5) help in decision-making, as interest rates close to those observed in the table will indicate the decision to be made by the investor. According to Portal Brasil (2017), for this type of business, which reduces impacts and preserves the environment, BNDES offers a funding line at an interest rate of $8.50 \%$ a.a., which represents a great possibility of success in the investment, given the present results. 


\section{Table 5}

Summary of Monte Carlo simulations of net present value (NPV) for hurdle rates (HR) ranging from 10 to $90 \%$ of the implementation and use of the infrastructure to recycle bedding sand from a free-stall facility for dairy cows in southern Minas Gerais, in the years 2016 to 2017, for Monte Carlo simulations 1 (MCS1) and 2 (MCS2)

\begin{tabular}{|lcc|}
\hline HR (\%) & Probability of NPV>0 MCS1 (\%) & Probability of NPV>0 MCS2 (\%) \\
\hline 10 & 100.00 & 100.00 \\
20 & 100.00 & 100.00 \\
30 & 100.00 & 100.00 \\
\hline 40 & 100.00 & 100.00 \\
\hline 50 & 100.00 & 100.00 \\
60 & 100.00 & 100.00 \\
70 & 100.00 & 100.00 \\
\hline 80 & 100.00 & 97.00 \\
\hline 90 & 68.00 & 49.00 \\
\hline
\end{tabular}

\section{Conclusions}

The implementation of the infrastructure to recycle bedding sand from a free-stall facility for dairy cows showed economic viability, with a positive net present value, internal rate of return above the analyzed hurdle rates, simple and discounted payback below the proposed horizon and satisfactory cost benefit ${ }^{-1}$ ratio (greater than 1 ).

The effective operating cost of one cubic meter of recycled sand was estimated at $\mathrm{R} \$ 5.04, \mathrm{R} \$ 4.51$ and $\mathrm{R} \$ 5.72$ for scenarios 1,2 and 3 , respectively. The average total cost of one cubic meter, considering all scenarios, was $\mathrm{R} \$ 6.84(+0.81)$, which is below the purchase value of $\mathrm{R} \$ 28.57$ at the sand extraction site.

Total costs were $\mathrm{R} \$ 37,219.51$ and $\mathrm{R} \$ 34,637.74$ for scenarios with hurdle rates of 8.50 and $6.99 \%$, respectively, whereas the total operating cost was $R \$ 22,572.08$, in all analyzed scenarios.
The total estimated annual sand consumption by the farm was $526.44 \mathrm{~m}^{3}$, or $1.23 \mathrm{~m}^{3}(+0.28)$ bed $^{-1}$ year ${ }^{-1}$. In all scenarios, the amount of sand recycled was approximately nine times greater than the estimated equilibrium point, which was $443.87,438.59$ and $450.74 \mathrm{~m}^{3}$ for scenarios 1,2 and 3 , respectively, at an interest rate of $6.99 \%$.

All Monte Carlo simulation models exhibited positive net present values. The simulations indicate a high probability of this economic indicator being above expectations, and the hurdle rate of up to $90 \%$ reflects a high probability of a positive net present value.

\section{Acknowledgments}

The authors would like to thank the INSTITUTO FEDERAL DE CIÊNCIA E TECNOLOGIA DE RONDONIA (IFRO) for the financial support in translating this paper, CAPES for granting of a scholarship to the 
second author, and Fazenda Catete, for making available the property data for the study.

\section{References}

Ako, T. A., Onoduku, U. S., Oke, S. A., Essien, B. I., Idris, F. N., Umar., A. N., \& Ahmed, A. A. (2014). Environmental effects of sand and gravel mining on land and soil in Luku, Minna, Niger State, North Central Nigeria. Journal of Geosciences and Geomatics. Newark, 2(2), 42-49. doi: 10.12691/jgg-22-1

Banco Central do Brasil (2018). Dólar americano. Recuperado de http://www4. bcb.gov.br/pec/taxas/port/ ptaxnpesq. asp?id=t xcotacao

Barbari, M., Monti, M., Rossi, G., Simonini, S., \& Guerri, F. S. (2014a). Proposal for a simple method of structural calculation for ordinary earthen buildings in rural areas. Journal of Food, Agriculture \& Environment, 12(2), 897-903. Recuperado de https://www. researchgate.net/publication/275291723_ Proposal_for_a_simple_method_of_ structural_calculation_for_ordinary_ earthen_buildings_in_rural_areas

Barbari, M., Monti, M., Rossi, G., Simonini, S., \& Guerri, F. S. (2014b). Simple methods and tools to determine the mechanical strength of adobe in rural areas. Journal of Food, Agriculture \& Environment, 12(2), 904-909. Recuperado de https://www.researchgate. net/publication/275292515_Simple_ methods_and_tools_to_determine_the mechanical_strength_of_adobe_in_rural_ areas

Bradley, A. J., Leach, K. A., Green, M. J., Gibbons, J., Ohnstad, I. C., Black, D. H.,... Breen, J. E. (2018). The impact of dairy cows' bedding material and its microbial content on the quality and safety of milk: a cross sectional study of UK farms. International Journal of Food Microbiology, 269, 36-45. doi: 10. 1016/j.ijfoodmicro.2017.12.022

Brondino, O. C., Silva, J. P. G., \& Brondino, N. C. M. (2014). O problema do descarte da areia de fundição: ensino para o desenvolvimento sustentável. Anais da Engenharia: Múltiplos Saberes e Atuações, Juiz de Fora, MG, Brasil. Recuperado de http:// www.abenge.org.br/cobenge/arquivos/5/ Artigos/129851.pdf

Chenço, E. C. (2016). Fundamentos em finanças. Curitiba: IESDE Brasil AS.

Conti, L., Goli, G., Monti, M., Pellegrini, P., Rossi, G., \& Barbari, M. (2017). Simplified method for the characterization of Rectangular Straw Bales (RSB) thermal conductivity. IOP Conference Series: Materials Science and Engineering, 245(5), 052035. doi: 10.1088/1757-899X/245/5/052035

Cook, S., Weitzman, M., Auinger, P., Nguyen, M., \& Dietz, W. H. (2003). Prevalence of a metabolic syndrome phenotype in adolescents: findings from the third National Health and Nutrition Examination Survey 1988-1994. Archives of Pediatrics \& Adolescent Medicine, 157(8), 821-827. doi: 10.1001/ archpedi.157.8.821

Espejo, L. A., Endres, M. I., \& Salfer, J. A. (2006). Prevalence of lameness in high-producing Holstein cows housed in freestall barns in Minnesota. Journal of Dairy Science, 89(8), 3052-3058. doi: 10.3168/jds.SO 022-0302(06)72579-6

Haack, S. C., \& Oliveira, G. G. de. (2013). Análise de viabilidade econômica e financeira de projetos sustentáveis no setor energético: estudo de caso para implantação de biodigestores no semiárido baiano. Revista Econômica do Nordeste, 44(Supl.), 363-382. Recuperado de https://ren. emnuvens.com.br/ren/ article/view/36/18 
Haraguchi, M., Siddiqi, A., \& Narayanamurti, V. (2019). Stochastic cost-benefit analysis of urbanwaste-to-energysystems. Journal of Cleaner Production, 224(3), 751-765. doi: 10.1016/j.jclepro.2019.03.099

Kristula, M. A., Rogers, W., Hogan, J. S., \& Sabo, M. (2005). Comparison of bacteria populations in clean and recycled sand used for bedding in dairy facilities. Journal of Dairy Science, 88(12), 4317-4325. doi: 10.3168/jds.S0022-0302(05)73118-0

Kumar, P., Elsaidi, H., Zorniak, B., Laurens, E., Yang, J., Bacchu, V.,... Wiebe, L. (2016). Synthesis and biological evaluation of iodoglucoazomycin (I-GAZ), an azomycinglucose adduct with putative applications in diagnostic imaging and radiotherapy of hypoxic tumors. Chem Med Chem, 11(15), 1638-1645. doi: 10.1002/ cmdc. 201600213

Lage, L. A., Lopes, M. A., Lopes, F. C. F., Gama, M. A. S., Ribeiro, C. G. S., Rodríguez, N. M., \& Demeu, F. A. (2016). Economic feasibility of adding sunflower oil to elephant grass-based diets of lactating dairy cows. Semina: Ciências Agrárias, 37/4, Supl. 1), 2313-2320. doi: 10.5433/16790359.2016v37 n4Supl1p2313

Laponni, J. (2007). Projetos de investimento na empresa. Rio de Janeiro: Elsevier Brasil.

Lelles, L. C., Silva, E., Griffith, J. J., \& Martins, S. V. (2005). Perfil ambiental qualitativo da extração de areia em cursos d'água. Revista Árvore, 29(3), 439-444. doi: 10.1590/S0100-67622005000300011

Leso, L., Conti, L., Rossi, G., \& Barbari, M. (2018). Criteria of design for deconstruction applied to dairy cows housing: a case study in Italy. Agronomy Research, 16, 794-805. doi: 10.15159/AR.18.085

Lopes, M. A., Junqueira, L. V., Bruhn, F. R. P., Demeu, A. A., \& Silva, M. das D. (2017).
Technical efficiency and economic viability of different cattle identification methods allowed by the Brazilian traceability system. Semina: Ciências Agrárias, 38(1), 467480. doi: 10.5433/1679-0359.2017v38n1 p467

Lopes, M. A., Moraes, F. de, Bruhn, F. R. P., Carvalho, F. de M., Lima, A. L. R., Reis, B. E. M., \& Viafara, J. A. S. (2019). Análisis de la rentabilidad de la actividad lechera de propriedades participantes del programa "Balde Cheio". Revista de Medicina Veterinaria, 38(1), 15-27. doi: 10.19052/ mv.vol1.iss38.2

Lopes, M. A., Reis, E. M. B., Demeu, F. A., Mesquita, A. A., Rocha, A. G. F., Pelegrini, D. F.,... Teixeira, F. E. P., Jr. (2016). Uso de ferramentas de gestão na atividade leiteira: um estudo de caso no sul de Minas Gerais. Revista Científica de Produção Animal, 18(1), 26-44. doi: 10.25066/ agrotec.v39i1.34302

Lopes, M. A., Vieira, J. A., Lima, F. H.S. de, Demeu, F. A., Bruhn, F. R. P., Pereira, A.,... Casas, P. S. (2018). Technical and economic efficiency of bovine weighing methods. Semina: Ciências Agrárias, 39(3), 1167-1180. doi: 10.5433/1679-0359.2018v39n3p1167

Moraes, F., Lopes, M. A., Carvalho, F. M., Peres, A. A. C., Bruhn, F. R. P., Lima, A. L. R., \& Cardoso, M. G. (2018). Effect of the scale of production on the cost-effectiveness of milk production systems belonging to the "Balde Cheio" program. Semina: Ciências Agrárias, 39(3), 1211-1224. doi: 10.5433/ 1679-0359.2018v39n3p1211

Norring, M., Manninen, E., Passille, A. M. de, Rushen, J., Munksgaard, L., \& Saloniemi, H. (2008). Effects of sand and straw bedding on the lying behavior, cleanliness, and hoof and hock injuries of dairy cows. Journal of Dairy Science, 91(2), 570-576. doi: 10.3168/jds.2007-0452 
Oliveira, A. D., \& Macedo, R. L. G. (1996). Sistemas agroflorestais: considerações técnicas e econômicas. (Projeto de Consultoria). Lavras: Ed. UFLA.

Oliveira, M. H. F., Almeida, M. R., \& Rebelatto, D. A. N. (2009). Avaliação de investimentos sob condições de incerteza: a aplicação do método de Monte Carlo em um estudo de caso no setor sucroalcoleiro. Anais do Encontro Nacional de Engenharia de Produção. A Engenharia de Produção e o Desenvolvimento Sustentável: Integrando Tecnologia e Gestão, Salvador, BA, Brasil, 29.

Pelegrini, D. P., Lopes, M. A., Demeu, F. A., Rocha, A. G. F., Bruhn, F. R. P., \& Casas, O. S. (2019). Effect of socioeconomic factors on the yields of family-operated milk production systems. Semina: Ciências Agrárias, 40(3), 1199-1214. doi: 10.5433/1679-0359.2019v40n3p1199

Portal Brasil (2017). Caderneta de poupança: índices mensais: rendimentos creditados no dia $1^{\circ}$ de cada mês. Brasília, DF. Recuperado de http://www.portalbrasil. net/poupanca_mensal.htm

Rocha, Á. G. F., \& Gaworski, M. (2017). Sand losses out the pens in barn with free-stall housing system. Agronomy Research, 15(2), 530-539. Recuperado de https://agronomy.emu.ee/wp-content/ uploads/2017/04/Vol15nr2_Rocha.pdf \#abstract-5154
Rossi, G., Conti, L., Bambi, G., Monti, M., \& Barbari, M. (2018). Poultry farming solutions for a sustainable development of marshlands areas of South Iraq. Agronomy Research, 16(2), 574-581. doi: 10.15159/ AR.18.058

Tobias, A. C., Rocha, A. C., Ferreira, F., \& Sousa, M. de M. (2010). Avaliação dos impactos ambientais causados pela extração de areia no leito do rio Piracanjuba, município de Silvania GO. Enciclopédia Biosfera, 6(11), 1-8. Recuperado de https:// docplayer.com.br/6797088-Avaliacaodos-impactos-ambientais-causadospela-extracao-de-areia-no-leito-do-riopiracanjuba-municipio-de-silvania-go. html

Torres, O. F. (2006). Fundamentos da engenharia econômica e da análise de projetos. São Paulo: Thomson Learning.

Zdanowicz, M., Shelford, J. A., Tucker, C. B., Weary, D., \& Keyserlingk, M. (2004). Bacterial populations on teat ends of dairy cows housed in free stalls and bedded with either sand or sawdust. Journal of Dairy Science, 87(6), 1694-1701. doi: 10.3168/ jds.S0022-0302(04)73322-6 